\title{
Microfluidic Approaches for Cancer Cell Separation: Review
}

\author{
Omer Osman Saeed, Rui Li, Yulin Deng \\ School of Life Science, Beijing Institute of Technology, Beijing, China \\ Email: omerphy2007@yahoo.com
}

Received 17 August 2014; revised 3 October 2014; accepted 17 October 2014

Copyright (C) 2014 by authors and Scientific Research Publishing Inc.

This work is licensed under the Creative Commons Attribution International License (CC BY). http://creativecommons.org/licenses/by/4.0/

\begin{abstract}
This article reviews the recent developments in microfluidic technologies for in vitro cancer diagnosis. We summarize the working principles and experimental results of microfluidic platforms for cancer cell detection, and separation based on magnetic activated micro-sorting, and differences in cellular biophysics (e.g., cell size and dielectrophoresis (DEP)).
\end{abstract}

Keywords

Microfluidic, Cancer Cell, Detentions, Separations

\section{Introduction}

Cancer is a class of diseases characterized by the uncontrolled growth of cells that ultimately invade surrounding tissues and metastasize to distant sites within the body [1] [2]. Early cancer detection is crucial for improved prognosis and cancer management due to the small tumor size and localization of the tumor at the primary site [3] [4]. Conventional cancer cell sorting techniques, which have been reviewed elsewhere [5] [6] including centrifugation, chromatography, and fluorescence and magnetic-activated cell sorting, are limited in yield and purity and further rely on the expertise and subjective judgments of highly skilled personnel. The small sample volumes, fast processing times, multiplexing capabilities, and large surface to volume ratios inherent in microfluidic systems [7] [8] offer new opportunities for cytology and cyto-pathology [9]-[18] particularly for in vitro cell sorting and detection [17] [19]-[25]. Leveraging these advantages, various microfluidic platforms have been developed for capturing rare cells including circulating tumor cells (CTCs), circulating fetal cells, and stem cells. Microfluidic sorting of rare cells has been reviewed elsewhere [26]-[29].

In this review, we focus on the application of microfluidic systems for cancer cell detection and sorting. We first present the development and working principle of several key microfluidic platforms including those based on magnetic activated cell sorting [30]-[39] and differences in cellular biophysics (e.g., cell size [40]-[53] and 
dielectrophoresis (DEP) [54]-[89]. We discuss the performance and capabilities of each system in terms of throughput, yield, purity, cell viability, and the capability for on-chip post-processing after cancer cell capture.

\section{Magnetic Activated Micro-Cell Sorters}

Magnetics based flow detection can enable several improvements in cytometry-based analyses. Magnetic detectors are extremely small (tens of micrometers) and rugged, representing an intriguing opportunity to reduce the size and complexity of cytometers for field-deployment. The small footprint also points to the potential to create highly multiplexed systems with hundreds of parallel channels and dramatically increase sample throughput. Magnetic activated cell sorting relies on the interaction between cell surface antigens and antibodies conjugated to suspended magnetic particles Compared to cell-affinity micro-chromatography, where the retrieval of captured cancer cells can be difficult, magnetic bead-based techniques readily permit the manipulation of captured cancer cells using local magnetic fields Table 1. Liu and Pang et al. demonstrated the first microfluidic device for isolating low abundance cancer cells from a red blood cell (RBC) suspension using magnetic cell separation Figure 1(A). In this system, a hexagonal array of nickel micro-pillars was integrated onto the bottom of a micro-fluidic channel and used to generate magnetic field gradients to efficiently trap super paramagnetic beads. The trapped magnetic beads functioned as a capture zone, followed by in situ chemical and biological modifications to functionalize the surface of beads with specific antibodies. Based on the interaction between the specific antibodies and N-acetylglucosamine on the cell membrane, A549 cancer cells spiked in RBCs were effectively captured and sorted on the microfluidic device with a capture rate between $62 \%$ and $74 \%$. Antibody-coated magnetic beads were also used in a micro-fluidic device for the serial selection of cell subpopulations. As illustrated in Figure 1(B), this separation system consists of two separate compartments, each containing magnetic beads functionalized with different surface membrane protein receptors specific to prostate cancer cells (PSMA and CD10). As a cell suspension is introduced to the first array, the cells expressing CD10 are immobilized onto the magnetic beads while CD10 cells pass through this chamber and into the second compartment. PSMA+ cells bind to the magnetic beads located in the second compartment after which the remaining cells are flushed from the system. Thus, PSMA+/CD10 and CD10+ prostate cancer cell subpopulations can be isolated.

In order to further increase the surface-to-volume ratio of magnetic beads for cell sorting, Saliba and Viovy et al. developed a method using columns of bio-functionalized super-para-magnetic beads self-assembled in a microfluidic channel. In this system, a hexagonal array of magnetic ink was first patterned at the bottom of microfluidic channels. Beads coated with anti-bodies were then injected into the channel and allowed to settle down. Upon application of an external vertical magnetic field, the magentic beads assembled on top of the ink dots to form a regular array of columns.

Tests using cell line mixtures demonstrated a capture recovery rate greater than $94 \%$ and the capability to cultivate the captured cells on chip. Furthermore, clinical samples (blood, pleural effusion, and fine needle aspirates) from healthy donors and patients with B-cell hematological malignant tumors were analyzed in the microfluidic chamber. Lien and Lee reported Multi-functional, integrated microfluidic devices capable of cancer cell separation, cell lysis and genetic identification. This platform consisted of an incubation module where target cancer cells are selectively captured onto functionalized magnetic beads, a control module for sample transportation, and a nucleic acid amplification module for cell lysis and genetic identification Figure 1(C). Cancer cells (e.g., lung and ovarian carcinoma) were spiked into whole blood samples and loaded into the incubation chamber with pre-loaded magnetic beads coated with monoclonal antibodies. The cancer cells were specifically immobilized onto the surface of the magnetic beads with a recovery rate higher than $90 \%$.

\section{Size-Based Cancer Cell Capture and Separation}

Differences in cell size can be exploited for microfluidic cancer cell selection without the knowledge of target cells' biochemical characteristics. Size-based cell separation is attractive, for instance, for capturing CTCs since these cells are much larger than other cells found in whole blood Table 2. Mohamed et al. reported the first size-based microfluidic cancer cell separation device which featured on-chip micro-filters. The device consisted of four regions with decreasing channel widths $(20 \mathrm{~mm}, 15 \mathrm{~mm}, 10 \mathrm{~mm}$, and $5 \mathrm{~mm}$ ) and a constant channel depth $(20 \mathrm{~mm})$. Cultured neuroblastoma cells mixed with whole blood were injected into the device where the $10 \mathrm{~mm}$ wide channels trapped the cancer cells. Zheng and Tai et al. developed a parylene membrane micro-filter device with circular holes (10 mm diameter) with a center to center distance between adjacent pores of $20 \mathrm{~mm}$. 
Table 1. Magnetic activated micro-cell sorters for cancer cell capture.

\begin{tabular}{|c|c|c|c|c|}
\hline Cell capture structures & Targeted cells & $\begin{array}{l}\text { Carrier medium and } \\
\text { control cells }\end{array}$ & $\begin{array}{c}\text { Target cell } \\
\text { recovery rate }\end{array}$ & Capture purity \\
\hline $\begin{array}{l}\text { A nickel micropillar } \\
\text { array + magnetic } \\
\text { beads functionalized with } \\
\text { wheat germ agglutinin }\end{array}$ & $\begin{array}{l}\text { Human lung cancer } \\
\text { cells of A549 }\end{array}$ & $\begin{array}{l}\text { Human RBCs + } \\
\text { culture medium }\end{array}$ & $62 \%-74 \%$ & $\begin{array}{l}\text { 93\% (initial ratio } \\
\text { A549:RBCs 1/4 1:10) }\end{array}$ \\
\hline $\begin{array}{l}\text { A paramagnetic array of } 80 \% \\
\text { Ni and } 20 \% \mathrm{Fe}^{+} \text {magnetic } \\
\text { beads complementary to } \\
\text { anti-CD10 antibodies in } \\
\text { chamber } 1 \text { and anti-PSMA } \\
\text { antibodies in chamber } 2\end{array}$ & $\begin{array}{l}\text { Human prostate } \\
\text { cancer cells of } \\
\text { LNCaP incubated } \\
\text { with PSMA } \\
\text { antibodies }\end{array}$ & $\begin{array}{l}\text { LNCaP incubated with } \\
\text { CD10 antibodies + PBS }\end{array}$ & $\begin{array}{l}50 \%-70 \% \text { of } \\
\text { LNCaP incubated } \\
\text { with PSMA } \\
\text { antibodies in } \\
\text { chamber } 2\end{array}$ & $\begin{array}{c}10 \% \text { of LNCaP } \\
\text { incubated with CD10 } \\
\text { antibodies in chamber } 2 \\
\text { (initial mixture ratio of } \\
\text { 1:1) }\end{array}$ \\
\hline $\begin{array}{l}\text { External permanent magnet } \\
\text { + magnetic beads coated } \\
\text { with Anti-EpCAM (Ber-EP4) }\end{array}$ & $\begin{array}{l}\text { Human ovarian cancer } \\
\text { cells of BG-1 and } \\
\text { lung cancer } \\
\text { cells of AS2 }\end{array}$ & $\begin{array}{l}\text { Blood samples from healthy } \\
\text { donors }\left(10^{6} \text { cells per ml }\right)\end{array}$ & $\begin{array}{l}95.1 \% \text { for BG-1 } \\
\text { cells and } 92.7 \% \\
\text { for AS2 cells }\end{array}$ & NA \\
\hline $\begin{array}{c}\text { An array of magnetic } \\
\text { dots + self-assembled } \\
\text { magnetic beads coated } \\
\text { with anti-CD19 antibodies }\end{array}$ & $\begin{array}{l}\text { Human lymphoma } \\
\text { cells of Raji CCL-86 }\end{array}$ & $\begin{array}{l}\text { Human lymphoma cells of } \\
\text { Jurkat TIB152 + PBS } \\
\left(2 \times 10^{6} \text { cells per ml }\right)\end{array}$ & $\begin{array}{l}97 \% \pm 2 \% \text { of } \\
\text { Raji cells }\end{array}$ & $\begin{array}{l}<2 \% \text { (capture of } \\
\text { Jurkat TIB152 cells) }\end{array}$ \\
\hline $\begin{array}{l}\text { An array of magnetic } \\
\text { dots + self-assembled } \\
\text { magnetic beads coated with } \\
\text { anti-CD19 antibodies }\end{array}$ & $\begin{array}{l}\text { B-cell hematological } \\
\text { malignant tumors } \\
\text { (leukemia and } \\
\text { lymphoma) }\end{array}$ & $\begin{array}{l}\text { Clinical samples (blood, pleural } \\
\text { effusion, and fine needle aspirates) } \\
\text { from chronic lymphocytic } \\
\text { leukemia, mantle cell lymphoma, } \\
\text { follicular lymphoma and two } \\
\text { healthy volunteers }\end{array}$ & \multicolumn{2}{|c|}{$\begin{array}{l}\text { Consistent immunophenotype and } \\
\text { morphology results with those obtained } \\
\text { by flow cytometry }\end{array}$} \\
\hline $\begin{array}{c}\text { External permanent } \\
\text { magnet }+ \text { self-assembled } \\
\text { magnetic bead patterns } \\
\text { coated with 5D10 antibodies }\end{array}$ & $\begin{array}{l}\text { Human breast cancer } \\
\text { cells of MCF-7 }\end{array}$ & $\begin{array}{l}\text { Human lymphoma cells of } \\
\text { Jurkat TIB152 + PBS } \\
\text { (106ells per ml for both } \\
\text { MCF-7 and Jurkat cells) }\end{array}$ & $\begin{array}{c}85 \% \pm 10 \% \text { of } \\
\text { MCF-7 }\end{array}$ & $\begin{array}{l}<5 \% \text { (capture of } \\
\text { Jurkat } \\
\text { TIB152 cells) }\end{array}$ \\
\hline $\begin{array}{l}\text { A nickel micropillar } \\
\text { array + magnetic } \\
\text { beads functionalized } \\
\text { with wheat germ } \\
\text { agglutinin }\end{array}$ & $\begin{array}{l}\text { Human lung cancer } \\
\text { cells of A549 }\end{array}$ & PBS & \multicolumn{2}{|c|}{$\begin{array}{l}\text { A total mass of } 90.6 \mathrm{ng} \text { of } \\
\text { captured A549 cells }\end{array}$} \\
\hline $\begin{array}{c}\text { External permanent } \\
\text { magnet }+\mathrm{Fe}_{3} \mathrm{O}_{4} \\
\text { magnetic nanoparticles } \\
\text { conjugated to } \\
\text { Anti-EpCAM }\end{array}$ & $\begin{array}{l}\text { Human colon cancer } \\
\text { cells of COLO205 and } \\
\text { human breast cancer } \\
\text { cells of SK-BR-3 }\end{array}$ & $\begin{array}{l}\text { Blood samples from } \\
\text { healthy donors }\end{array}$ & $\begin{array}{l}90 \% \text { and } 86 \% \text { for } \\
\text { COLO205 and } \\
\text { SK-BR-3 } \\
\text { cells, respectively }\end{array}$ & NA \\
\hline
\end{tabular}

The size difference between CTCs and human blood cells was exploited to test 57 blood samples from patients with metastatic prostate, breast, colon, or bladder cancer. The results demonstrated CTC capture and identification in 51 of 57 patients compared with only 26 patients in 57 patients using the cell membrane during the trapping process, and the device enabled via CTC conventional Cell Search method. However, this process resulted in low capture cell viability due to the large stresses that developed in the cell membrane during the cell capture process. Zheng and Tai et al. further developed a double-membrane device to decrease stresses experienced by capture Figure 2(A). In this device, a second porous membrane was incorporated below the first membrane. The por positions between the two membranes were intentionally misaligned. This bottom membrane provided support for the trapped cells to effectively reduce flow-induced stress on the cell membrane. Tan and Lim et al. developed a microfluidic device with multiple arrays of crescent-shaped wells Figure 2(B) to isolate cancer cells from spiked blood [68] and patient whole-blood samples. Gaps (5 mm) were made within each of the crescent-shaped traps to ensure the complete removal of other blood constituents due to their ability to traverse narrow constrictions. After cancer cell capture, a reverse flow was used to retrieve the captured cancer cells from the device. Isolation efficiencies higher than $80 \%$ were achieved for breast and colon cancer cell lines. In addition, this device was able to successfully detect and retrieve CTCs from the peripheral blood of patients with 


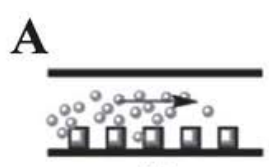

(a)

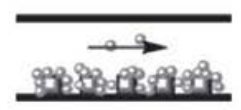

(b)

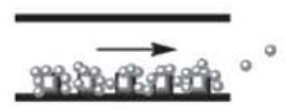

(c)

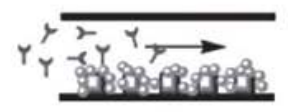

(d)

- Superparamagnetic bead

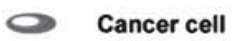

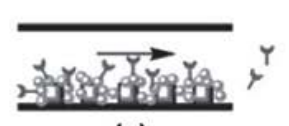

(e)

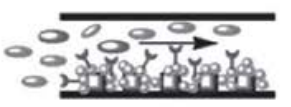

(f)

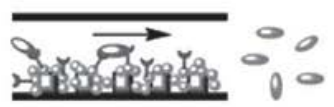

(g)

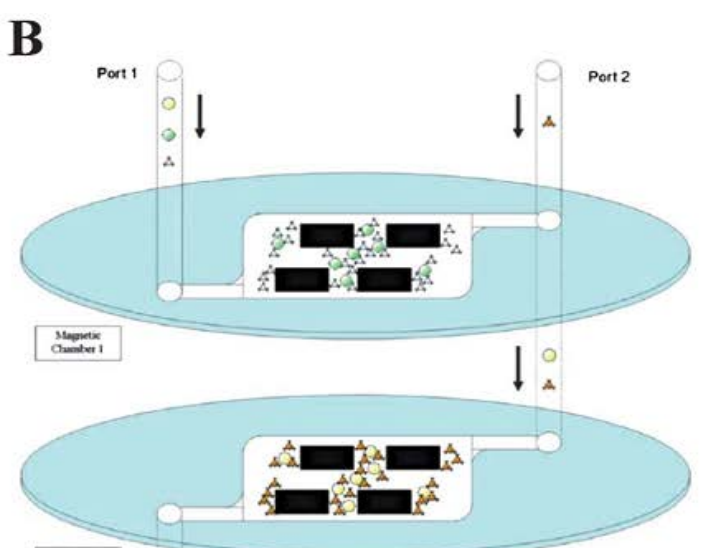

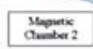

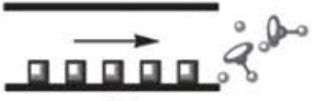

(h)

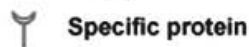

- Normal cell
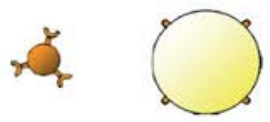

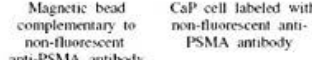
complementary to
non-lluorescent
anti-PSMA antibody

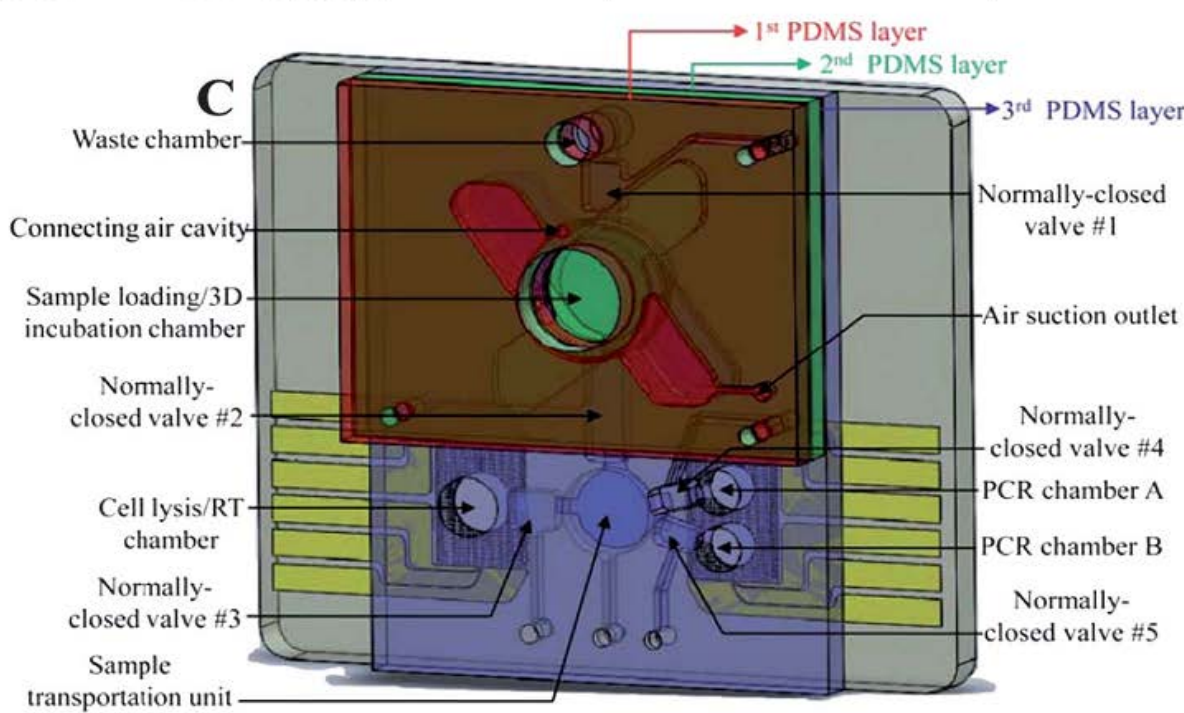

Figure 1. Magnetic activated micro-cell sorters. (A) Step by step illustration of the first magnetic activated micro-cell sorter for cancer cell capture. (B) Schematic of a microfluidic device for serial selection of cellular subpopulations by the use of antibody-coated magnetic beads. (C) An integrated magnetic-based cancer cell capture platform, consisting of an incubator for the magnetic beads to capture cancer cells, a control module for sample transportation, and a nucleic acid amplification module for cell lysis and genetic identification.

metastatic lung cancer. Di Carlo et al. utilized microscale laminar vortices combined with inertial focusing to selectively isolate and trap larger cancer cells spiked into whole blood while smaller blood cells were flushed out of the device Figure 2(C). Multiple micro scale laminar vortices were created on chip with processing rates as high as $7.5 \times 10^{6}$ cells per second. The reported cell recovery rates for these devices were $23 \%$ for MCF-7 cells and $10 \%$ for HeLa cells.

\section{Dielectrophoresis}

Dielectrophoresis (DEP) uses the polarization of cells in non-uniform electrical fields to exert forces on cells. DEP forces depend on factors such as cell membrane and cytoplasm electrical properties as well as cell size. 


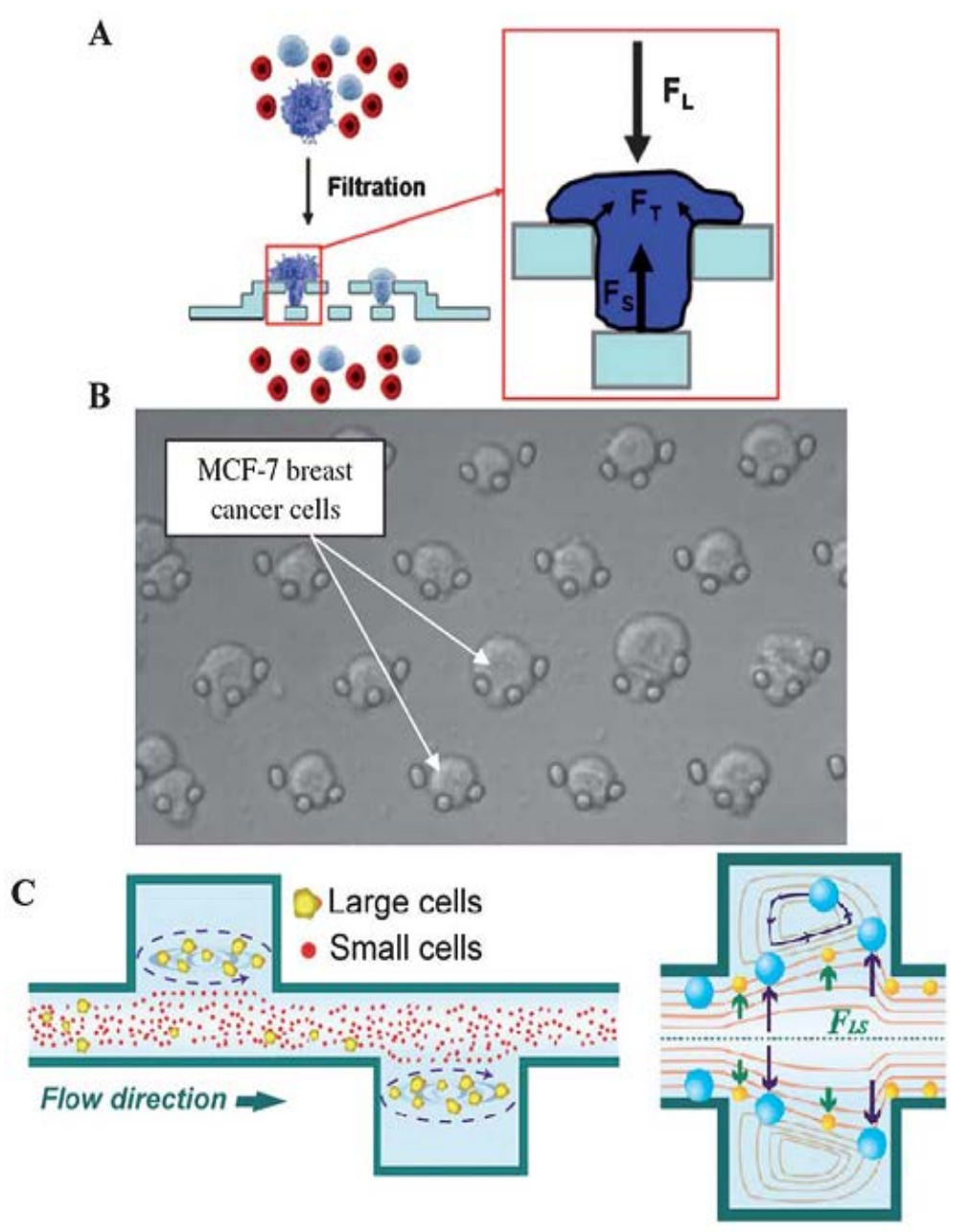

Figure 2. Microfluidic devices for cancer cell capture and separation based on cell size differences. (A) A 3D parylene membrane micro-filter. (B) A PDMS micro-filter with crescent-shaped isolation wells captured cancer cells. (C) A microdevice for trapping large cells and eluting small cells by combining microscale laminar vortices with inertial focusing.

DEP devices have been developed for separating cancer cells Table 3, based on differences in cells' response to electric fields [90]. Becker and Gascoyne et al. reported the first dielectric affinity column Figure 3(A) for cancer cell separation in which human leukaemia cells suspended within normal blood cells were retained on microelectrode arrays while normal blood cells were eluted [91]. The cancer cells were subsequently released for collection by the removal of the DEP field. Becker and Gascoyne et al. further demonstrated the applicability of this method for the separation of epithelial cancer cells (MDA-231 cells) from diluted blood and reported a recovery rate of 95\% [92] [93].

Gascoyne et al. proposed DEP flow-field fractionation (DEP-FFF) wherein DEP forces are generated to levitate suspended cells to different equilibrium heights within amicrofluidic chamber, based on variations of cells' electrical properties [94]. The levitated cells are transported at different flow velocities upon the application of fluid flow Figure 3(B). Using this approach, human leukemic (HL-60) cells, 99, 106 MDA-435 cells, 101, 102 MDA-468 cells and MDA-231 cells 113 were successfully separated from background cell populations. To enhance sorting sensitivities, a 3D-asymmetric microelectrode setup was developed for cancer cell separation Figure 3(C). An alternative method for separating cancer cells has been demonstrated by combining multi-orifice flow fractionation (MOFF) with DEP.

Figure 3(D), when cell samples were introduced through the inlet, most of the blood cells were separated via 
Table 2. Cell size-based cancer cell separation microfluidic devices.

\begin{tabular}{|c|c|c|c|c|}
\hline Cell capture structures & Targeted cells & $\begin{array}{l}\text { Carrier medium and } \\
\text { control cells }\end{array}$ & $\begin{array}{c}\text { Target cell } \\
\text { recovery rate }\end{array}$ & Capture purity \\
\hline $\begin{array}{c}\text { Four successively } \\
\text { narrower } \\
\text { polyurethane channels }\end{array}$ & $\begin{array}{c}\text { Human neuroblastoma } \\
\text { cells }\end{array}$ & $\begin{array}{l}\text { Human whole blood or } \\
\text { isolated mononuclear cells } \\
\text { in PBS }\end{array}$ & NA & NA \\
\hline $\begin{array}{l}\text { Glass based pool and } \\
\text { dam structure }\end{array}$ & $\begin{array}{l}\text { Human lung cancer } \\
\text { cells of SPC-A- }\end{array}$ & $\begin{array}{l}\text { Human blood from healthy } \\
\text { donors }\left(10^{6} \mathrm{RBCs} \text { and } 2 \times\right. \\
\left.10^{5} \text { cancer cells }\right)\end{array}$ & $99.9 \%$ & NA \\
\hline $\begin{array}{l}\text { One-layer parylene-C } \\
\text { membrane micro-filters }\end{array}$ & $\begin{array}{l}\text { Human prostate cancer } \\
\text { cells of LNCaP }\end{array}$ & $\begin{array}{l}\text { Human blood samples from } \\
\text { healthy donors ( } 50 \text { - } 500 \text { cell } \\
\text { per ml) }\end{array}$ & $89.5 \% \pm 9.5 \%$ & NA \\
\hline $\begin{array}{l}\text { One-layer parylene-C } \\
\text { membrane micro-filter }\end{array}$ & $\begin{array}{c}\text { Human breast cancer cells of } \\
\text { MCF-7, SK-Br-3, and MDA-231, } \\
\text { bladder cancer cells of J82, T24 } \\
\text { andRT4 and prostate cancer cells } \\
\text { of LNCaP }\end{array}$ & $\begin{array}{l}\text { Human blood samples from } \\
\text { healthy donors (5 cells per } \\
\mathrm{ml})\end{array}$ & $\begin{array}{c}96.5 \% \text { ( } \geq 1 \text { cells }) \text { and } \\
64 \% \text { ( } \geq 3 \text { cells })\end{array}$ & NA \\
\hline $\begin{array}{l}\text { One-layer parylene-C } \\
\text { membrane micro-filter }\end{array}$ & CTCs & $\begin{array}{l}\text { Blood samples from patients } \\
\text { with metastatic prostate, breast, } \\
\text { colon, or bladder cancer }\end{array}$ & $\begin{array}{c}\text { CTC identification } \\
\text { in } 51 \text { of } 57 \text { patient } \\
\text { samples }\end{array}$ & NA \\
\hline $\begin{array}{l}\text { 3D parylene-C } \\
\text { membrane } \\
\text { micro-filters }\end{array}$ & $\begin{array}{l}\text { Human prostate cancer cells of } \\
\text { LNCaP and breast cancer } \\
\text { cells of MCF-7 }\end{array}$ & $\begin{array}{l}\text { Blood samples from health } \\
\text { donors }(\sim 3 \text { MCF-7 and } \\
\sim 100 \text { LNCaP cells per ml) }\end{array}$ & $86.5 \% \pm 5.3 \%$ & NA \\
\hline $\begin{array}{l}\text { PDMS based crescent } \\
\text { shaped isolation wells }\end{array}$ & $\begin{array}{l}\text { Human breast and cancer cells of } \\
\text { MCF-7 and MDA-231, colon } \\
\text { cancer cells of HT-29 }\end{array}$ & $\begin{array}{l}\text { Blood samples from healthy } \\
\text { donors (100 cancer cells per } \\
\mathrm{ml})\end{array}$ & $>80 \%$ & $>80 \%$ \\
\hline $\begin{array}{l}\text { PDMS based crescent } \\
\text { shaped isolation well }\end{array}$ & $\begin{array}{l}\text { Human breast cancer cells of } \\
\text { MCF-7 and MDA-231, gastric } \\
\text { cancer cells of AGS and N87, } \\
\text { hepatocellular cancer cells of } \\
\text { HepG2 and HuH7, tongue cancer } \\
\text { cells of CAL27 and pharynx } \\
\text { cancer cells of FADU }\end{array}$ & $\begin{array}{l}\text { PBS and whole blood } \\
\text { samples from healthy } \\
\text { donors (100 cancer cells per } \\
\text { ml) }\end{array}$ & $\sim 80 \%$ & $\begin{array}{l}\text { Mean value } \\
\text { of } 89 \%\end{array}$ \\
\hline $\begin{array}{l}\text { PDMS based crescent } \\
\text { shaped isolation wells }\end{array}$ & CTCs & $\begin{array}{l}\text { Blood samples from patients } \\
\text { with metastatic lung cancer }\end{array}$ & $\begin{array}{l}\text { CTC identification in } 5 \\
\text { of } 5 \text { patient samples }\end{array}$ & $\begin{array}{l}\text { Mean value } \\
\text { of } 83 \%\end{array}$ \\
\hline $\begin{array}{l}\text { Size-selective } \\
\text { micro-cavity } \\
\text { arrays made of nickel }\end{array}$ & $\begin{array}{l}\text { Human lung cancer cells of } \\
\text { NCI-H358, breast cancer cells of } \\
\text { MCF-7, gastric cancer cells of } \\
\text { AGS and SNU-1, and colon } \\
\text { cancer cells of SW620 }\end{array}$ & $\begin{array}{l}\text { Blood samples from healthy } \\
\text { donors }(10 \text { - } 100 \text { cancer cells } \\
\text { per ml })\end{array}$ & $>80 \%$ & NA \\
\hline $\begin{array}{l}\text { PDMS based dam } \\
\text { structures + lectin } \\
\text { cocanavalin } \mathrm{A}\end{array}$ & Human leukemic cells of K562 & $\begin{array}{l}\text { Blood from healthy mice } \\
\left(10^{6} \mathrm{RBCs} \text { and } 2 \times\right. \\
\left.10^{5} \mathrm{~K} 562 \text { cells }\right)\end{array}$ & $84 \%$ & NA \\
\hline $\begin{array}{l}\text { Polyurethane-methacrylate } \\
\text { based lateral micro-filters } \\
\text { with arrays of pillars }\end{array}$ & $\begin{array}{l}\text { Human breast cancer cells of } \\
\text { MCF-7 (fixed and unfixed) }\end{array}$ & $\begin{array}{c}\text { Blood samples from healthy } \\
\text { donors }\end{array}$ & $\begin{array}{l}\text { 90\% (fixed cancer } \\
\text { cells) and } 50 \% \\
\text { (unfixed cells }\end{array}$ & NA \\
\hline $\begin{array}{l}\text { Inertial flow in spiral } \\
\text { micro-channels } \\
\text { made of PDMS }\end{array}$ & $\begin{array}{l}\text { Human neuroblastoma cells } \\
\text { ofSH-SY5Y and rat glioma } \\
\text { cells of C6 }\end{array}$ & PCB & $\sim 80 \%$ & NA \\
\hline $\begin{array}{l}\text { PDMS based expansion- } \\
\text { contraction reservoirs to } \\
\text { produce micro-vortices }\end{array}$ & $\begin{array}{c}\text { Human cervical cancer cells of } \\
\text { HeLa and breast cancer cells of } \\
\text { MCF-7 }\end{array}$ & $\begin{array}{l}\text { Blood samples containing } \\
\text { leukocytes only (1:100 of } \\
\text { cancer cells to leukocytes) }\end{array}$ & $\begin{array}{l}\sim 23 \% \text { (MCF-7) } \\
\text { and } 10 \% \text { (HeLa) }\end{array}$ & $\begin{array}{l}\text { 7.1-fold } \\
\text { enrichment for } \\
\text { MCF-7 and 5.5-fold }\end{array}$ \\
\hline $\begin{array}{l}\text { PDMS based high aspect } \\
\text { ratio rectangular } \\
\text { micro-channels patterned } \\
\text { with a contraction- } \\
\text { expansion array }\end{array}$ & $\begin{array}{c}\text { Human breast cancer cells of } \\
\text { MCF-7 }\end{array}$ & $\begin{array}{l}\text { PBS and blood samples (500 } \\
\text { MCF-7 cells per ml) }\end{array}$ & $\begin{array}{l}>90 \% \text { (MCF-7 in } \\
\text { PBS) and } \sim 80 \% \\
\text { (MCF-7 in blood } \\
\text { samples }\end{array}$ & $\begin{array}{c}3.3 \times 10^{5} \text {-fold } \\
\text { enrichment over } \\
\text { RBCs and } 1.2 \times \\
10^{4} \text {-fold enrichment } \\
\text { over } \\
\text { leukocytes }\end{array}$ \\
\hline
\end{tabular}



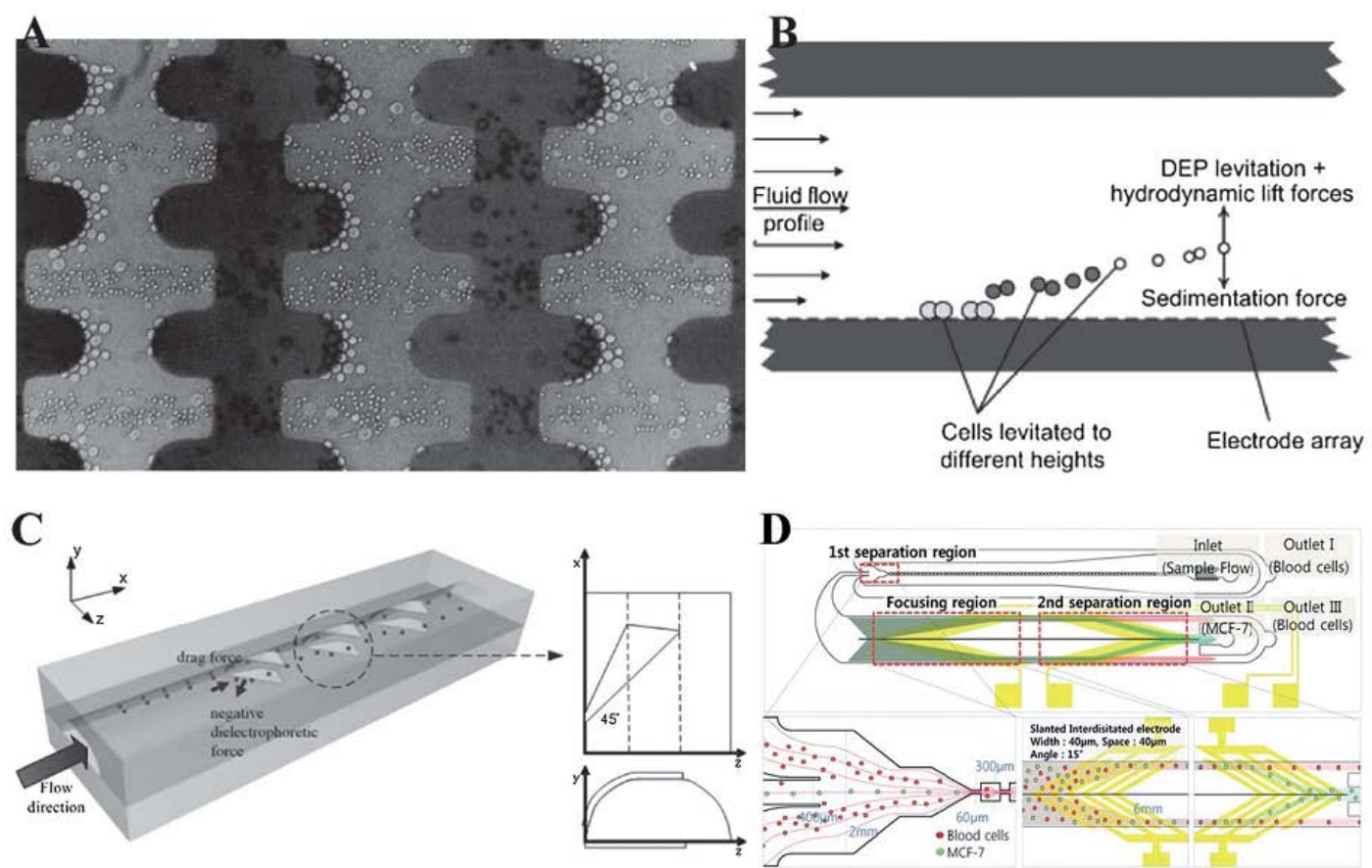

Figure 3. Microfluidic DEP devices for cancer cell separation. (A) A dielectric affinity column for cancer cell separation where large cancer cells are trapped on electrode tips while small blood cells are eluted. (B) DEP-FFF combines DEP, sedimentation and hydrodynamic forces to influence cell positions in the hydrodynamic flow profile. (C) A 3D-asymmetric microelectrode system for DEP cell separation, reproduced with permission. (D) A continuous separator integrates multiorifice flow fractionation and DEP.

MOFF and extracted through outlet I while MCF-7 cells with residual blood cells (not fully separated) proceeded to the DEP separator. At the DEP separator, cancer cells exited through outlet II while the residual blood cells passed through outlet III. Since the DEP technique leverages differences in both cellular size and dielectric properties, it could potentially lead to a higher cancer cell separation yield and purity compared to micro-filtration methods that are based on cell size differences only. However, in practice, due to the limited dielectric differences between target cells and carrier cells, this technique's yield and purity are not as high as expected in Table 3. Among the detection techniques discussed in this review, on-chip DEP is the only technique that has not yet undergone verifications with clinical samples. Thus, an approach that utilizes a combination of multiple cell-capture methods may prove viable for improving the performance of cancer cell capture devices. For example, to improve device selectivity and cell-capture efficiency, one may envision a multi-module microfluidic system for cancer cell capture in which the first module performs high-throughput concentration and purification of target cells while a second module enables the selective capture of cancer cells. Such a device can be realized by integrating DEP with cell affinity micro-chromatography, such as for CTC detection. The DEP module would function as a pre-concentrator to increase the concentration of CTCs by flushing samples through channels patterned with electrodes. The concentrated samples would then enter the cell affinity micro-chromatography module for high-purity CTC capture.

\section{Conclusion and Outlook}

This review summarized the working principles and experimental results of key microfluidic technologies for cancer cell separation and detection. These microfluidic devices are based on magnetic activated micro-cell sorting, size-based microfluidic separation, and dielectrophoresis. Despite the recent technological advances, the development of a single device capable of simultaneously achieving high throughput, high target cancer cell recovery, high purity, and high cell viability remains challenging. Magnetic activated cell sorting readily permits the manipulation of captured cancer cells by controlling local magnetic fields for post-capture processing. Lien and Lee et al. proposed a multi functional, integrated magnetic bead-based microfluidic device capable of cancer 
Table 3. DEP-based cancer cell separation microfluidic devices.

\begin{tabular}{|c|c|c|c|c|}
\hline Cell capture structures & Targeted cells & $\begin{array}{l}\text { Carrier medium and } \\
\text { control cells }\end{array}$ & $\begin{array}{c}\text { Target cell } \\
\text { recovery rate }\end{array}$ & Capture purity \\
\hline $\begin{array}{c}\text { An electrode affinity } \\
\text { column with interdigitated } \\
\text { micro-electrodes }\end{array}$ & $\begin{array}{l}\text { Human leukemic } \\
\text { cells of HL-60 }\end{array}$ & $\begin{array}{l}\text { Blood cells + } \\
\text { sucrose solution }\end{array}$ & NA & $\begin{array}{l}\sim 80 \% \text { (initial mixture of } 2 \\
\times 10^{7} \text { HL-60 and } 3 \times 10^{7} \\
\text { blood cells) }\end{array}$ \\
\hline $\begin{array}{l}\text { A dielectric affinity column } \\
\text { with interdigitated } \\
\text { micro-electrodes }\end{array}$ & $\begin{array}{l}\text { Human breast cancer } \\
\text { cells of MDA-231 }\end{array}$ & $\begin{array}{l}\text { Blood samples } \\
+ \text { sucrose } \\
\text { solution }\end{array}$ & NA & $\begin{array}{c}\sim 95 \% \text { (initial mixture of } \\
1 \times 10^{7} \text { MDA-231 and } \\
3 \times 10^{7} \text { blood cells) }\end{array}$ \\
\hline $\begin{array}{c}\text { A dielectric affinity column } \\
\text { with an interdigitated } \\
\text { micro-electrodes }\end{array}$ & $\begin{array}{l}\text { Human breast cancer } \\
\text { cells of MDA-231 }\end{array}$ & $\begin{array}{l}\text { Blood samples } \\
+ \text { sucrose } \\
\text { solution }\end{array}$ & $>95 \%$ & NA \\
\hline $\begin{array}{c}\text { A dielectric affinity column } \\
\text { with reconfigurable } \\
\text { electrodes }\end{array}$ & $\begin{array}{c}\text { Human cervical cancer } \\
\text { cells of HeLa }\end{array}$ & $\begin{array}{l}\text { Human peripheral } \\
\text { blood cells }+ \\
\text { sucrose solution }\end{array}$ & NA & NA \\
\hline $\begin{array}{c}\text { A dielectric affinity column } \\
\text { with a micro-electrode } \\
\text { array }\end{array}$ & $\begin{array}{c}\text { Human monocytic cells of } \\
\text { U937, lymphoma cells of } \\
\text { Jurkat, HTLV-1, tax-transformed } \\
\text { human T cells of Ind-2, glioma } \\
\text { cells of HTB, and } \\
\text { neuroblastoma cells of SH-SY5Y }\end{array}$ & $\begin{array}{l}\text { Peripheral blood } \\
\text { mononuclear } \\
\text { cells + sucrose } \\
\text { solution }\end{array}$ & $47 \%-79 \%$ & $>95 \%$ \\
\hline $\begin{array}{l}\text { DEP field flow fraction with } \\
\text { interdigitated electrodes }\end{array}$ & $\begin{array}{l}\text { Human leukemic } \\
\text { cells of HL-60 }\end{array}$ & $\begin{array}{l}\text { WBCs from blood } \\
\text { samples }+ \\
\text { sucrose solution }\end{array}$ & NA & NA \\
\hline $\begin{array}{l}\text { DEP field flow fraction with } \\
\text { interdigitated electrodes }\end{array}$ & $\begin{array}{l}\text { Human breast cancer } \\
\text { cells of MDA-435 }\end{array}$ & $\begin{array}{c}\text { Hematopoietic } \\
\text { CD34+ stem } \\
\text { cells + sucrose solution }\end{array}$ & NA & $\begin{array}{l}>99 \% \text { (initial MDA-435: } \\
\text { stem cells = 2:3) }\end{array}$ \\
\hline $\begin{array}{l}\text { DEP field flow fraction with } \\
\text { interdigitated electrodes }\end{array}$ & $\begin{array}{l}\text { Human breast cancer } \\
\text { cells of MDA-435 }\end{array}$ & $\begin{array}{l}\text { Blood samples + } \\
\text { sucrose solution }\end{array}$ & NA & $\begin{array}{l}>98 \% \text { of MDA-435 } \\
\text { (initialMDA-435: } \\
\text { blood cells = 2:3) }\end{array}$ \\
\hline $\begin{array}{l}\text { DEP field flow fraction with } \\
\text { interdigitated electrodes }\end{array}$ & $\begin{array}{c}\text { Human breast cancer cells of } \\
\text { MDA-435, MDA-468 and } \\
\text { MDA-231 }\end{array}$ & $\begin{array}{c}\text { Peripheral blood } \\
\text { mononuclear } \\
\text { cells + sucrose solution }\end{array}$ & $>90 \%$ & NA \\
\hline $\begin{array}{l}\text { Microscope slides coated } \\
\text { with electrode arrays with } \\
\text { changing frequencies }\end{array}$ & $\begin{array}{l}\text { Human breast cancer cells of } \\
\text { MDA-435 and leukemic } \\
\text { cells of HL-60 }\end{array}$ & $\begin{array}{l}\text { Blood samples } \\
+ \text { sucrose }\end{array}$ & NA & NA \\
\hline $\begin{array}{l}\text { Microscope slides coated } \\
\text { with electrode arrays with } \\
\text { changing frequencies }\end{array}$ & Cancer cells from biopsy & $\begin{array}{l}\text { Biopsied cells } \\
+ \text { sucrose } \\
\text { solution }\end{array}$ & NA & NA \\
\hline $\begin{array}{c}\text { 3D-asymmetric micro-electrodes } \\
\text { with a continuously varied } \\
\text { electric field }\end{array}$ & $\begin{array}{l}\text { Mouse P19 embryonic } \\
\text { carcinoma cells }\end{array}$ & Mouse RBCs + PBS & NA & $\begin{array}{c}81.5 \% \pm 7.6 \% \text { of } \mathrm{P} 19 \mathrm{EC} \\
\text { and } 94.1 \% \pm 4.3 \% \mathrm{RBCs} \\
\quad \text { (initial ratio } 1: 1 \text { ) }\end{array}$ \\
\hline $\begin{array}{l}\text { 3D-asymmetric micro-electrodes } \\
\text { with a continuously varied } \\
\text { electric field }\end{array}$ & $\begin{array}{c}\text { Human breast cancer cells of } \\
\text { MCF-7 and MCF-10A }\end{array}$ & PBS & $\begin{array}{l}86.67 \% \text { of } \\
\mathrm{MCF}-7 \text { and } \\
98.73 \% \text { of } \\
\mathrm{MCF}-10 \mathrm{~A}\end{array}$ & NA \\
\hline DC-dielectrophoresis & $\begin{array}{l}\text { Fixed WBCs and human breast } \\
\text { cancer cells of MCF-7 }\end{array}$ & Trehalose solution & NA & NA \\
\hline $\begin{array}{l}\text { Guided DEP with a pair of } \\
\text { planar electrodes }\end{array}$ & $\begin{array}{l}\text { Human leukemic cells of Jurkat } \\
\text { and cervical cancer cells of } \\
\text { HeLa }\end{array}$ & Sucrose solution & NA & NA \\
\hline $\begin{array}{l}\text { Planar interdigitated } \\
\text { Microelectrodes }\end{array}$ & $\begin{array}{l}\text { Clones of mouse melanoma } \\
\text { B16F10 cells }\end{array}$ & Sucrose solution & NA & NA \\
\hline $\begin{array}{l}\text { A planar electrode pair with } \\
\text { an angle to the flow } \\
\text { direction }\end{array}$ & $\begin{array}{l}\text { Human colorectal cancer cells } \\
\text { of HCT116 and embryonic } \\
\text { kidney cells of HEK } 293\end{array}$ & PBS & NA & $95 \%$ of HCT116 \\
\hline
\end{tabular}


cell separation, cell lysis, and genetic identification. Microfiltration methods also permit easy retrieval of captured cancer cells, as demonstrated by Tan and Lim et al., using a reverse flow to release captured cancer cells in multiple arrays of crescent-shaped wells. However, on-chip post-capture processing capabilities have yet to be developed.

However, existing systems are only capable of processing small numbers of cells within a reasonable time frame. For example, the total number of cells tested by the optical stretcher was 36 for MCF-10, 26 for MCF-7, and 21 for Mod-MCF-7.81. Reported electrical impedance spectroscopy differences of head and neck cancer cell lines with different metastatic potentials (686LNvs.686LN-M4e) were also based on the testing of low sample numbers $(\mathrm{n}=72$ for the 686LN-M4e cell and $\mathrm{n}=57$ for the 686LN cell). Furthermore, most microfluidic devices to date have been only capable of characterizing a single biophysical parameter.

The broad spectrum of cell separation technologies described in this review illustrates the high level of interest and activity in this area. The described size based approaches offer a great potential for separation of cell subpopulations for which specific markers are not known or cannot be used (e.g., to prevent cell activation). Affinity-based approaches (magnetic and electrophoretic) can be employed for fast ( minutes) and continuous separation with high specificity ( 99\%). For all of the approaches, the design of the devices is such that they can be operated in a massively parallel fashion to increase scale and throughput without compromising purity and efficacy; although each technique has some limitations e.g. in sized based, the probability of cells damages is high and it is considered as nonspecific technique. The magnetic activated micro-cell sorters are easy to develop but the time required for screening the tumor is relatively long. Regarding DEP, the need to control precisely laminar flow conditions and the electric field frequencies is a more critical point. A challenge for microfluidic cancer cell's biophysical characterization is existing devices that have low sample throughput. To obtain clinically relevant information, these devices must be able to measure biophysical properties of a large number of cells with true high throughputs.

\section{Acknowledgements}

This work was done by the Nanotechnology Research Group in School of Life Science, Beijing Institute of Technology.

\section{References}

[1] Ruddon, R.W. and Ebrary Inc. (2007) Cancer Biology. 3rd Edition, Oxford University Press, New York.

[2] Jemal, A., Siegel, R., Xu, J.Q. and Ward, E. (2010) Cancer Statistics. A Cancer Journal for Clinicians, 60, $277-300$. http://dx.doi.org/10.3322/caac.20073

[3] Bannasch, P. (1992) Cancer Diagnosis: Early Detection. Springer, Berlin. http://dx.doi.org/10.1007/978-3-642-76899-6

[4] Dunn, B.K., Verma, M. and Umar, A. (2003) Epigenetics in Cancer Prevention: Early Detection and Risk Assessment. Annals of the New York Academy of Sciences, 983, 1-4.

[5] Armakolas, A., Panteleakou, Z., Nezos, A., Tsouma, A., Skondra, M., Lembessis, P., Pissimissis, N. and Koutsilieris, M. (2010) Detection of the Circulating Tumor Cells in Cancer Patients. Future Oncology, 6, 1849-1856. http://dx.doi.org/10.2217/fon.10.152

[6] Zieglschmid, V., Hollmann, C. and Bocher, O. (2005) Detection of Disseminated Tumor Cells in Peripheral Blood. Critical Reviews in Clinical Laboratory Sciences, 42, 155-196. http://dx.doi.org/10.1080/10408360590913696

[7] Young, E.W.K. and Beebe, D.J. (2010) Fundamentals of Microfluidic Cell Culture in Controlled Microenvironments. Chemical Society Reviews, 39, 1036-1048. http://dx.doi.org/10.1039/b909900j

[8] Gascoyne, P.R.C. and Vykoukal, J. (2002) Particle Separation by Dielectrophoresis. Electrophoresis, 23, $1973-1983$. http://dx.doi.org/10.1002/1522-2683(200207)23:13<1973::AID-ELPS1973>3.0.CO;2-1

[9] Gossett, D.R., Weaver, W.M., Mach, A.J., Hur, S.C., Tse, H.T.K., Lee, W., Amini, H. and Di Carlo, D. (2010) Label-Free Cell Separation and Sorting in Microfluidic Systems. Analytical and Bioanalytical Chemistry, 397, 3249-3267. http://dx.doi.org/10.1007/s00216-010-3721-9

[10] Didar, T.F. and Tabrizian, M. (2010) Adhesion Based Detection, Sorting and Enrichment of Cells in Microfluidic Lab-on-Chip Devices. Lab on a Chip, 10, 3043-3053. http://dx.doi.org/10.1039/c0lc00130a

[11] Pratt, E.D., Huang, C., Hawkins, B.G., Gleghorn, J.P. and Kirby, B.J. (2011) Rare Cell Capture in Microfluidic Devices. Chemical Engineering Science, 66, 1508-1522. http://dx.doi.org/10.1016/j.ces.2010.09.012 
[12] Zborowski, M. and Chalmers, J.J. (2011) Rare Cell Separation and Analysis by Magnetic Sorting. Analytical Chemistry, 83, 8050-8056. http://dx.doi.org/10.1021/ac200550d

[13] Du, Z., Colls, N., Cheng, K.H., Vaughn, M.W. and Gollahon, L. (2006) Microfluidic-Based Diagnostics for Cervical Cancer Cells. Biosensors and Bioelectronics, 21, 1991-1995. http://dx.doi.org/10.1016/j.bios.2005.09.005

[14] Wankhede, S.P., Du, Z., Berg, J.M., Vaughn, M.W., Dallas, T., Cheng, K.H. and Gollahon, L. (2006) Cell Detachment Model for an Antibody-Based Microfluidic Cancer Screening System. Biotechnology Progress, 22, 1426-1433. http://dx.doi.org/10.1021/bp060127d

[15] Du, Z., Cheng, K.H., Vaughn, M.W., Collie, N.L. and Gollahon, L.S. (2007) Recognition and Capture of Breast Cancer Cells. Biomed Microdevices, 9, 35-42. http://www.ncbi.nlm.nih.gov/pubmed/17103049

[16] Nagrath, S., Sequist, L.V., Maheswaran, S., Bell, D.W., Irimia, D., Ulkus, L., Smith, M.R., Kwak, E.L., Digumarthy, S., Muzikansky, A., Ryan, P., Balis, U.J., Tompkins, R.G., Haber, D.A. and Toner, M. (2007) Isolation of Rare Circulating Tumour Cells in Cancer Patients by Microchip Technology. Nature, 450, 1235-1239. http://dx.doi.org/10.1038/nature06385

[17] Adams, A.A., Okagbare, P.I., Feng, J., Hupert, M.L., Patterson, D., Gottert, J., McCarley, R.L., Nikitopoulos, D., Murphy, M.C. and Soper, S.A. (2008) Highly Efficient Circulating Tumor Cell Isolation from Whole Blood and LabelFree Enumeration Using Polymer-Based Microfluidics with an Integrated Conductivity Sensor. Journal of the American Chemical Society, 130, 8633-8641. http://dx.doi.org/10.1021/ja8015022

[18] Maheswaran, S., Sequist, L.V., Nagrath, S., Ulkus, L., Brannigan, B., Collura, C.V., Inserra, E., Diederichs, S., Iafrate, A.J., Bell, D.W., Digumarthy, S., Muzikansky, A., Irimia, D., Settleman, J., Tompkins, R.G., Lynch, T.J., Toner, M. and Haber, D.A. (2008) Detection of Mutations in EGFR in Circulating Lung-Cancer Cells. The New England Journal of Medicine, 359, 366-377. http://dx.doi.org/10.1056/NEJMoa0800668

[19] Wang, S.T., Wang, H., Jiao, J., Chen, K.J., Owens, G.E., Kamei, K.I., et al. (2009) Three-Dimensional Nanostructured Substrates toward Efficient Capture of Circulating Tumor Cells. Angewandte Chemie International Edition, 48, 89708973. http://dx.doi.org/10.1002/anie.200901668

[20] Gleghorn, J.P., Pratt, E.D., Denning, D., Liu, H., Bander, N.H., Tagawa, S.T., Nanus, D.M., Giannakakou, P.A. and Kirby, B.J. (2010) Capture of Circulating Tumor Cells from Whole Blood of Prostate Cancer Patients Using Geometrically Enhanced Differential Immunocapture (GEDI) and a Prostate-Specific Antibody. Lab on a Chip, 10, 27-29. http://dx.doi.org/10.1039/b917959c

[21] Stott, S.L., Hsu, C.H., Tsukrov, D.I., Yu, M., Miyamoto, D.T., Waltman, B.A., Rothenberg, S.M., Shah, A.M., Smas, M.E., Korir, G.K., Floyd, F.P., Gilman, A.J., Lord, J.B., Winokur, D., Springer, S., Irimia, D., Nagrath, S., Sequist, L. V., Lee, R.J., Isselbacher, K.J., Maheswaran, S., Haber, D.A. and Toner, M. (2010) Isolation of Circulating Tumor Cells Using a Microvortex-Generating Herringbone-Chip. Proceedings of the National Academy of Sciences of the United States of America, 107, 18392-18397. http://dx.doi.org/10.1073/pnas.1012539107

[22] Thierry, B., Kurkuri, M., Shi, J.Y., Lwin, L.E. and Palms, D. (2010) Herceptin Functionalized Microfluidic Polydimethylsiloxane Devices for the Capture of Human Epidermal Growth Factor Receptor 2 Positive Circulating Breast Cancer Cells. Biomicrofluidics, 4, Article ID: 032205. http://dx.doi.org/10.1063/1.3480573

[23] Dharmasiri, U., Njoroge, S.K., Witek, M.A., Adebiyi, M.G., Kamande, J.W., Hupert, M.L., Barany, F. and Soper, S.A. (2011) High-Throughput Selection, Enumeration, Electrokinetic Manipulation, and Molecular Profiling of Low-Abundance Circulating Tumor Cells Using a Microfluidic System. Analytical Chemistry, 83, 2301-2309. http://dx.doi.org/10.1021/ac103172y

[24] Kurkuri, M.D., Al-Ejeh, F., Shi, J.Y., Palms, D., Prestidge, C., Griesser, H.J., Brown, M.P. and Thierry, B. (2011) Plasma Functionalized PDMS Microfluidic Chips: Towards Point-of-Care Capture of Circulating Tumor Cells. Journal of Materials Chemistry, 21, 8841-8848. http://dx.doi.org/10.1039/c1jm10317b

[25] Wang, S.T., Liu, K., Liu, J.A., Yu, Z.T.F., Xu, X.W., Zhao, L.B., Lee, T., Lee, E.K., Reiss, J., Lee, Y.K., Chung, L. W.K., Huang, J.T., Rettig, M., Seligson, D., Duraiswamy, K.N., Shen, C.K.F. and Tseng, H.R. (2011) Highly Efficient Capture of Circulating Tumor Cells by Using Nanostructured Silicon Substrates with Integrated Chaotic Micromixers. Angewandte Chemie International Edition, 50, 3084-3088. http://dx.doi.org/10.1002/anie.201005853

[26] Li, N., Tourovskaia, A. and Folch, A. (2003) Biology on a Chip: Microfabrication for Studying the Behavior of Cultured Cells. Critical Review in Biomedical Engineering, 31, 423-488.

[27] Zheng, X., Cheung, L.S., Schroeder, J.A., Jiang, L. and Zohar, Y. (2011) A High-Performance Microsystem for Isolating Circulating Tumor Cells. Lab on a Chip, 11, 3269-3276. http://dx.doi.org/10.1039/c1lc20331b

[28] Dharmasiri, U., Balamurugan, S., Adams, A.A., Okagbare, P.I., Obubuafo, A. and Soper, S.A. (2009) Highly Efficient Capture and Enumeration of Low Abundance Prostate Cancer Cells Using Prostate-Specific Membrane Antigen Aptamers Immobilized to a Polymeric Microfluidic Device. Electrophoresis, 30, 3289-3300. http://dx.doi.org/10.1002/elps.200900141

[29] Phillips, J.A., Xu, Y., Xia, Z., Fan, Z.H. and Tan, W.H. (2009) Enrichment of Cancer Cells Using Aptamers Immobi- 
lized on a Microfluidic Channel. Analytical Chemistry, 81, 1033-1039. http://dx.doi.org/10.1021/ac802092j

[30] Lin, H.K., Zheng, S.Y., Williams, A.J., Balic, M., Groshen, S., Scher, H.I., Fleisher, M., Stadler, W., Datar, R.H., Tai, Y.C. and Cote, R.J. (2010) Portable Filter Based Microdevice for Detection and Characterization of Circulating Tumor Cells. Clinical Cancer Research, 16, 5011-5018. http://dx.doi.org/10.1158/1078-0432.CCR-10-1105

[31] Tan, S.J., Lakshmi, R.L., Chen, P.F., Lim, W.T., Yobas, L. and Lim, C.T. (2010) Versatile Label Free Biochip for the Detection of Circulating Tumor Cells from Peripheral Blood in Cancer Patients. Biosensors and Bioelectronics, 26, 1701-1705. http://dx.doi.org/10.1016/j.bios.2010.07.054

[32] Bhagat, A.A.S., Hou, H.W., Li, L.D., Lim, C.T. and Han, J.Y. (2011) Pinched Flow Coupled Shear-Modulated Inertial Microfluidics for High-Throughput Rare Blood Cell Separation. Lab on a Chip, 11, 1870-1878. http://dx.doi.org/10.1039/c0lc00633e

[33] Hur, S.C., Mach, A.J. and Di Carlo, D. (2011) High-Throughput Size-Based Rare Cell Enrichment Using Microscale Vortices. Biomicrofluidics, 5, Article ID: 022206. http://dx.doi.org/10.1063/1.3576780

[34] Moon, H.S., Kwon, K., Kim, S.I., Han, H., Sohn, J., Lee, S. and Jung, H.I. (2011) Continuous Separation of Breast Cancer Cells from Blood Samples Using Multi-Orifice Flow Fractionation (MOFF) and Dielectrophoresis (DEP). Lab on a Chip, 11, 1118-1125. http://dx.doi.org/10.1039/c0lc00345j

[35] Zheng, S.Y., Lin, H.K., Lu, B., Williams, A., Datar, R., Cote, R.J. and Tai, Y.C. (2011) 3D Microfilter Device for Viable Circulating Tumor Cell (CTC) Enrichment from Blood. Biomedical Microdevices, 13, 203-213. http://dx.doi.org/10.1007/s10544-010-9485-3

[36] Kwon, K.W., Choi, S.S., Lee, S.H., Kim, B., Lee, S.N., Park, M.C., Kim, P., Hwang, S.Y. and Suh, K.Y. (2007) LabelFree, Microfluidic Separation and Enrichment of Human Breast Cancer Cells by Adhesion Difference. Lab on a Chip, 7, 1461-1468. http://dx.doi.org/10.1039/b710054j

[37] Couzon, C., Duperray, A. and Verdier, C. (2009) Critical Stresses for Cancer Cell Detachment in Microchannels. European Biophysics Journal, 38, 1035-1047.

[38] Lincoln, B., Erickson, H.M., Schinkinger, S., Wottawah, F., Mitchell, D., Ulvick, S., Bilby, C. and Guck, J. (2004) Deformability-Based Flow Cytometry. Cytometry Part A, 59A, 203-209. http://dx.doi.org/10.1002/cyto.a.20050

[39] Guck, J., Schinkinger, S., Lincoln, B., Wottawah, F., Ebert, S., Romeyke, M., Lenz, D., Erickson, H.M., Ananthakrishnan, R., Mitchell, D., Käs, J., Ulvick, S. and Bilby, C. (2005) Optical Deformability as an Inherent Cell Marker for Testing Malignant Transformation and Metastatic Competence. Biophysical Journal, 88, 3689-3698. http://dx.doi.org/10.1529/biophysj.104.045476

[40] Kim, Y.C., Park, S.J. and Park, J.K. (2008) Biomechanical Analysis of Cancerous and Normal Cells Based on Bulge Generation in a Microfluidic Device. Analyst, 133, 1432-1439. http://dx.doi.org/10.1039/b805355c

[41] Hou, H.W., Li, Q.S., Lee, G.Y.H., Kumar, A.P., Ong, C.N. and Lim, C.T. (2009) Deformability Study of Breast Cancer Cells Using Microfluidics. Biomedical Microdevices, 11, 557-564. http://dx.doi.org/10.1007/s10544-008-9262-8

[42] Chen, J., Abdelgawad, M., Yu, L.M., Shakiba, N., Chien, W.Y., Lu, Z., Geddie, W.R., Jewett, M.A.S. and Sun, Y. (2011) Electrodeformation for Single Cell Mechanical Characterization. Journal of Micromechanics and Microengineering, 21, Article ID: 054012.

[43] Chen, J., Zheng, Y., Tan, Q., Shojaei-Baghini, E., Zhang, Y.L., Li, J., Prasad, P., You, L., Wu, X.Y. and Sun, Y. (2011) Classification of Cell Types Using a Microfluidic Device for Mechanical and Electrical Measurement on Single Cells. Lab on a Chip, 11, 3174-3181. http://dx.doi.org/10.1039/c1lc20473d

[44] Hur, S.C., Henderson-MacLennan, N.K., McCabe, E.R.B. and Di Carlo, D. (2011) Deformability-Based Cell Classification and Enrichment Using Inertial Microfluidics. Lab on a Chip, 11, 912-920. http://dx.doi.org/10.1039/c0lc00595a

[45] Labeed, F.H., Coley, H.M., Thomas, H. and Hughes, M.P. (2003) Assessment of Multidrug Resistance Reversal Using Dielectrophoresis and Flow Cytometry. Biophysical Journal, 85, 2028-2034. http://dx.doi.org/10.1016/S0006-3495(03)74630-X

[46] Cen, E.G., Dalton, C., Li, Y.L., Adamia, S., Pilarski, L.M. and Kaler, K.V.I.S. (2004) A Combined Dielectrophoresis, Traveling Wave Dielectrophoresis and Electrorotation Microchip for the Manipulation and Characterization of Human Malignant Cells. Journal of Microbiological Methods, 58, 387-401. http://dx.doi.org/10.1016/j.mimet.2004.05.002

[47] Broche, L.M., Labeed, F.H. and Hughes, M.P. (2005) Extraction of Dielectric Properties of Multiple Populations from Dielectrophoretic Collection Spectrum Data. Physics in Medicine and Biology, 50, 2267-2274. http://dx.doi.org/10.1088/0031-9155/50/10/006

[48] Chin, S., Hughes, M.P., Coley, H.M. and Labeed, F.H. (2006) Rapid Assessment of Early Biophysical Changes in K562 Cells during Apoptosis Determined Using Dielectrophoresis. International Journal of Nanomedicine, 1, 333-337.

[49] Labeed, F.H., Coley, H.M. and Hughes, M.P. (2006) Differences in the Biophysical Properties of Membrane and Cytoplasm of Apoptotic Cells Revealed Using Dielectrophoresis. Biochimica et Biophysica Acta (BBA), General Subjects, 1760, 922-929. 
[50] Broche, L.M., Bhadal, N., Lewis, M.P., Porter, S., Hughes, M.P. and Labeed, F.H. (2007) Early Detection of Oral Cancer-Is Dielectrophoresis the Answer? Oral Oncology, 43, 199-203. http://dx.doi.org/10.1016/j.oraloncology.2006.02.012

[51] Coley, H.M., Labeed, F.H., Thomas, H. and Hughes, M.P. (2007) Biophysical Characterization of MDR Breast Cancer Cell Lines Reveals the Cytoplasm Is Critical in Determining Drug Sensitivity. Biochimica et Biophysica Acta (BBA), General Subjects, 1770, 601-608.

[52] Duncan, L., Shelmerdine, H., Hughes, M.P., Coley, H.M., Hubner, Y. and Labeed, F.H. (2008) Dielectrophoretic Analysis of Changes in Cytoplasmic Ion Levels Due to Ion Channel Blocker Action Reveals Underlying Differences between Drug-Sensitive and Multidrug-Resistant Leukaemic Cells. Physics in Medicine and Biology, 53, N1-N7.

[53] Shim, S., Gascoyne, P., Noshari, J. and Hale, K.S. (2011) Dynamic Physical Properties of Dissociated Tumor Cells Revealed by Dielectrophoretic Field-Flow Fractionation. Integrative Biology, 3, 850-862. http://dx.doi.org/10.1039/c1ib00032b

[54] Kuo, J.S., Zhao, Y.X., Schiro, P.G., Ng, L.Y., Lim, D.S.W., Shelby, J.P. and Chiu, D.T. (2010) Deformability Considerations in Filtration of Biological Cells. Lab on a Chip, 10, 837-842. http://dx.doi.org/10.1039/b922301k

[55] Altomare, L., Borgatti, M., Medoro, G., Manaresi, N., Tartagni, M., Guerrieri, R. and Gambari, R. (2003) Levitation and Movement of Human Tumor Cells Using a Printed Circuit Board Device Based on Software-Controlled Dielectrophoresis. Biotechnology and Bioengineering, 82, 474-479. http://dx.doi.org/10.1002/bit.10590

[56] Das, C.M., Becker, F., Vernon, S., Noshari, J., Joyce, C. and Gascoyne, P.R.C. (2005) Dielectrophoretic Segregation of Different Human Cell Types on Microscope Slides. Analytical Chemistry, 77, 2708-2719. http://dx.doi.org/10.1021/ac048196z

[57] Hu, X.Y., Bessette, P.H., Qian, J.R., Meinhart, C.D., Daugherty, P.S. and Soh, H.T. (2005) Marker-Specific Sorting of Rare Cells Using Dielectrophoresis. Proceedings of the National Academy of Sciences of the United States of America, 102, 15757-15761. http://dx.doi.org/10.1073/pnas.0507719102

[58] Park, J., Kim, B., Choi, S.K., Hong, S., Lee, S.H. and Lee, K.I. (2005) An Efficient Cell Separation System Using 3DAsymmetric Microelectrodes. Lab on a Chip, 5, 1264-1270. http://dx.doi.org/10.1039/b506803g

[59] Kim, U., Shu, C.W., Dane, K.Y., Daugherty, P.S., Wang, J.Y.J. and Soh, H.T. (2007) Selection of Mammalian Cells Based on Their Cell-Cycle Phase Using Dielectrophoresis. Proceedings of the National Academy of Sciences of the United States of America, 104, 20708-20712. http://dx.doi.org/10.1073/pnas.0708760104

[60] Cristofanilli, M., Krishnamurthy, S., Das, C.M., Reuben, J.M., Spohn, W., Noshari, J., Becker, F. and Gascoyne, P.R. (2008) Dielectric Cell Separation of Fine Needle Aspirates from Tumor Xenografts. Journal of Separation Science, 31 , 3732-3739. http://dx.doi.org/10.1002/jssc.200800366

[61] Kang, Y.J., Li, D.Q., Kalams, S.A. and Eid, J.E. (2008) DC-Dielectrophoretic Separation of Biological Cells by Size. Biomedical Microdevices, 10, 243-249. http://dx.doi.org/10.1007/s10544-007-9130-y

[62] An, J., Lee, J., Lee, S.H., Park, J. and Kim, B. (2009) Separation of Malignant Human Breast Cancer Epithelial Cells from Healthy Epithelial Cells Using an Advanced Dielectrophoresis-Activated Cell Sorter (DACS). Analytical and Bioanalytical Chemistry, 394, 801-809. http://dx.doi.org/10.1007/s00216-009-2743-7

[63] Gascoyne, P.R.C., Noshari, J., Anderson, T.J. and Becker, F.F. (2009) Isolation of Rare Cells from Cell Mixtures by Dielectrophoresis. Electrophoresis, 30, 1388-1398. http://dx.doi.org/10.1002/elps.200800373

[64] Kostner, S., van den Driesche, S., Witarski, W., Pastorekova, S. and Vellekoop, M.J. (2010) Guided Dielectrophoresis: A Robust Method for Continuous Particle and Cell Separation. IEEE Sensors Journal, 10, 1440-1446. http://dx.doi.org/10.1109/JSEN.2010.2044787

[65] Sabuncu, A.C., Liu, J.A., Beebe, S.J. and Beskok, A. (2010) Dielectrophoretic Separation of Mouse Melanoma Clones. Biomicrofluidics, 4, Article ID: 021101. http://dx.doi.org/10.1063/1.3447702

[66] Yang, F., Yang, X.M., Jiang, H., Bulkhaults, P., Wood, P., Hrushesky, W. and Wang, G.R. (2010) Dielectrophoretic Separation of Colorectal Cancer Cells. Biomicrofluidics, 4, Article ID: 013204. http://dx.doi.org/10.1063/1.3279786

[67] Alazzam, A., Stiharu, I., Bhat, R. and Meguerditchian, A.N. (2011) Interdigitated Comb-Like Electrodes for Continuous Separation of Malignant Cells from Blood Using Dielectrophoresis. Electrophoresis, 32, 1327-1336. http://dx.doi.org/10.1002/elps.201000625

[68] Han, K.H., Han, A. and Frazier, A.B. (2006) Microsystems for Isolation and Electrophysiological Analysis of Breast Cancer Cells from Blood. Biosensors and Bioelectronics, 21, 1907-1914. http://dx.doi.org/10.1016/j.bios.2006.01.024

[69] Cho, Y., Kim, H.S., Frazier, A.B., Chen, Z.G., Shin, D.M. and Han, A. (2009) Whole-Cell Impedance Analysis for Highly and Poorly Metastatic Cancer Cells. Journal of Microelectromechanical Systems, 18, 808-817. http://dx.doi.org/10.1109/JMEMS.2009.2021821

[70] Mamouni, J. and Yang, L. (2011) Interdigitated Microelectrode-Based Microchip for Electrical Impedance Spectrosco- 
pic Study of Oral Cancer Cells. Biomedical Microdevices, 13, 1075-1088. http://dx.doi.org/10.1007/s10544-011-9577-8

[71] Yang, L.J., Arias, L.R., Lane, T.S., Yancey, M.D. and Mamouni, J. (2011) Real-Time Electrical Impedance-Based Measurement to Distinguish Oral Cancer Cells and Non-Cancer Oral Epithelial Cells. Analytical and Bioanalytical Chemistry, 399, 1823-1833. http://dx.doi.org/10.1007/s00216-010-4584-9

[72] Xu, Y.H., Yang, X.R. and Wang, E.K. (2010) Review: Aptamers in Microfluidic Chips. Analytica Chimica Acta, 683, 12-20. http://dx.doi.org/10.1016/j.aca.2010.10.007

[73] Voldman, J. (2006) Electrical Forces for Microscale Cell Manipulation. Annual Review of Biomedical Engineering, 8, 425-454. http://dx.doi.org/10.1146/annurev.bioeng.8.061505.095739

[74] Tay, F.E.H., Yu, L.M. and Iliescu, C. (2009) Particle Manipulation by Miniaturised Dielectrophoretic Devices. Defence Science Journal, 59, 595-604. http://dx.doi.org/10.14429/dsj.59.1564

[75] Zhang, C., Khoshmanesh, K., Mitchell, A. and Kalantar-zadeh, K. (2010) Dielectrophoresis for Manipulation of Micro/ Nano Particles in Microfluidic Systems. Analytical and Bioanalytical Chemistry, 396, 401-420. http://dx.doi.org/10.1007/s00216-009-2922-6

[76] Khoshmanesh, K., Nahavandi, S., Baratchi, S., Mitchell, A. and Kalantar-zadeh, K. (2011) Dielectrophoretic Platforms for Bio-Microfluidic Systems. Biosensors and Bioelectronics, 26, 1800-1814. http://dx.doi.org/10.1016/j.bios.2010.09.022

[77] Kim, D.H., Wong, P.K., Park, J., Levchenko, A. and Sun, Y. (2009) Microengineered Platforms for Cell Mechanobiology. Annual Review of Biomedical Engineering, 11, 203-233. http://dx.doi.org/10.1146/annurev-bioeng-061008-124915

[78] Loh, O., Vaziri, A. and Espinosa, H. (2009) The Potential of MEMS for Advancing Experiments and Modeling in Cell Mechanics. Experimental Mechanics, 49, 105-124. http://dx.doi.org/10.1007/s11340-007-9099-8

[79] Vanapalli, S.A., Duits, M.H.G. and Mugele, F. (2009) Microfluidics as a Functional Tool for Cell Mechanics. Biomicrofluidics, 3, Article ID: 012006. http://dx.doi.org/10.1063/1.3067820

[80] Rajagopalan, J. and Saif, M.T.A. (2011) MEMS Sensors Andmicrosystems for Cell Mechanobiology. Journal of Micromechanics and Microengineering, 21, Article ID: 054002.

[81] Zheng, X.Y.R. and Zhang, X. (2011) Microsystems for Cellular Force Measurement: A Review. Journal of Micromechanics and Microengineering, 21, Article ID: 054003.

[82] Zheng, Y. and Sun, Y. (2011) Microfluidic Devices for Mechanical Characterisation of Single Cells in Suspension. Micro \& Nano Letters, 6, 327-331. http://dx.doi.org/10.1049/mnl.2011.0010

[83] Morgan, H., Sun, T., Holmes, D., Gawad, S. and Green, N.G. (2007) Single Cell Dielectric Spectroscopy. Journal of Physics D: Applied Physics, 40, 61-70.

[84] Valero, A., Braschler, T. and Renaud, P. (2010) A Unified Approach to Dielectric Single Cell Analysis: Impedance and Dielectrophoretic Force Spectroscopy. Lab on a Chip, 10, 2216-2225. http://dx.doi.org/10.1039/c003982a

[85] Cheung, K.C., Di Berardino, M., Schade-Kampmann, G., Hebeisen, M., Pierzchalski, A., Bocsi, J., Mittag, A. and Tárnok, A. (2010) Microfluidic Impedance-Based Flow Cytometry. Cytometry Part A, 77A, 648-666.

http://dx.doi.org/10.1002/cyto.a.20910

[86] Cheung, L.S.L., Zheng, X.G., Stopa, A., Baygents, J.C., Guzman, R., Schroeder, J.A., Heimark, R.L. and Zohar, Y. (2009) Detachment of Captured Cancer Cells under Flow Acceleration in a Bio-Functionalized Microchannel. Lab on a Chip, 9, 1721-1731. http://dx.doi.org/10.1039/b822172c

[87] Wang, S.T., Wang, H., Jiao, J., Chen, K.J., Owens, G.E., Kamei, K.I., Sun, J., Sherman, D.J., Behrenbruch, C.P., Wu, H. and Tseng, H.R. (2009) Angewandte Chemie, 121, 9132; (2009) Angewandte Chemie International Edition in English, 48, 8970 .

[88] Squires, T.M. and Quake, S.R. (2005) Microfluidics: Fluid Physics at the Nanoliter Scale. Reviews of Modern Physics, 77, 977. http://dx.doi.org/10.1103/RevModPhys.77.977

[89] Whitesides, G.M. (2006) The Origins and the Future of Microfluidics. Nature, 442, 368-373. http://dx.doi.org/10.1038/nature05058

[90] Hoshino, K., Huang, Y.Y., Lane, N., Huebschman, M., Uhr, J.W., Frenkel, E.P. and Zhang, X. (2011) MicrochipBased Immunomagnetic Detection of Circulating Tumor Cells. Lab on a Chip, 11, 3449-3457. http://dx.doi.org/10.1039/c1lc20270g

[91] Mauk, M.G., Ziober, B.L., Chen, Z.Y., Thompson, J.A. and Bau, H.H. (2007) Lab-on-a-Chip Technologies for OralBased Cancer Screening and Diagnostics-Capabilities, Issues, and Prospects. Annals of the New York Academy of Sciences, 1098, 467-475. http://dx.doi.org/10.1196/annals.1384.025

[92] Estes, M.D., Ouyang, B., Ho, S.M. and Ahn, C.H. (2009) Isolation of Prostate Cancer Cell Subpopulations of Func- 
tional Interest by Use of an On-Chip Magnetic Bead-Based Cell Separator. Journal of Micromechanics and Microengineering, 19, Article ID: 095015.

[93] Lee, H., Yoon, T.J., Figueiredo, J.L., Swirski, F.K. and Weissleder, R. (2009) Rapid Detection and Profiling of Cancer Cells in Fine-Needle Aspirates. Proceedings of the National Academy of Sciences of the United States of America, 106, 12459-12464. http://dx.doi.org/10.1073/pnas.0902365106

[94] Chen, C.L., Chen, K.C., Pan, Y.C., Lee, T.P., Hsiung, L.C., Lin, C.M., Chen, C.Y., Lin, C.H., Chiang, B.L. and Wo, A. M. (2011) Separation and Detection of Rare Cells in a Microfluidic Disk via Negative Selection. Lab on a Chip, 11, 474-483. http://dx.doi.org/10.1039/c0lc00332h 
Scientific Research Publishing (SCIRP) is one of the largest Open Access journal publishers. It is currently publishing more than 200 open access, online, peer-reviewed journals covering a wide range of academic disciplines. SCIRP serves the worldwide academic communities and contributes to the progress and application of science with its publication.

Other selected journals from SCIRP are listed as below. Submit your manuscript to us via either submit@scirp.org or Online Submission Portal.
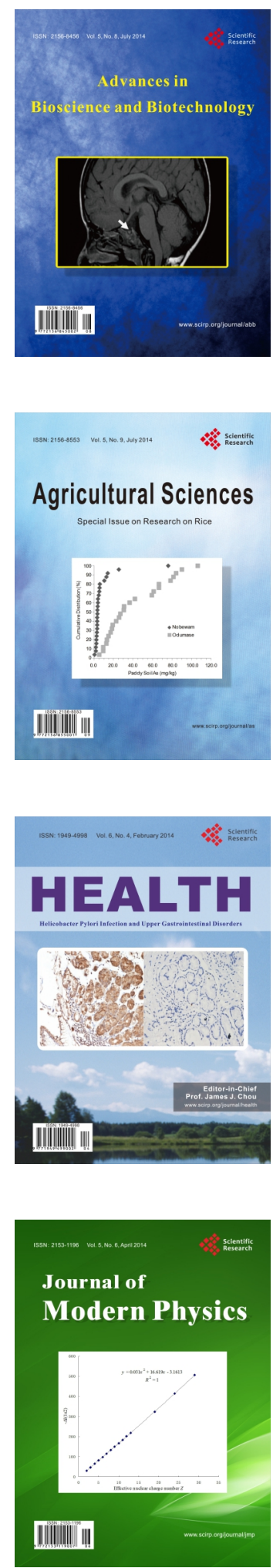
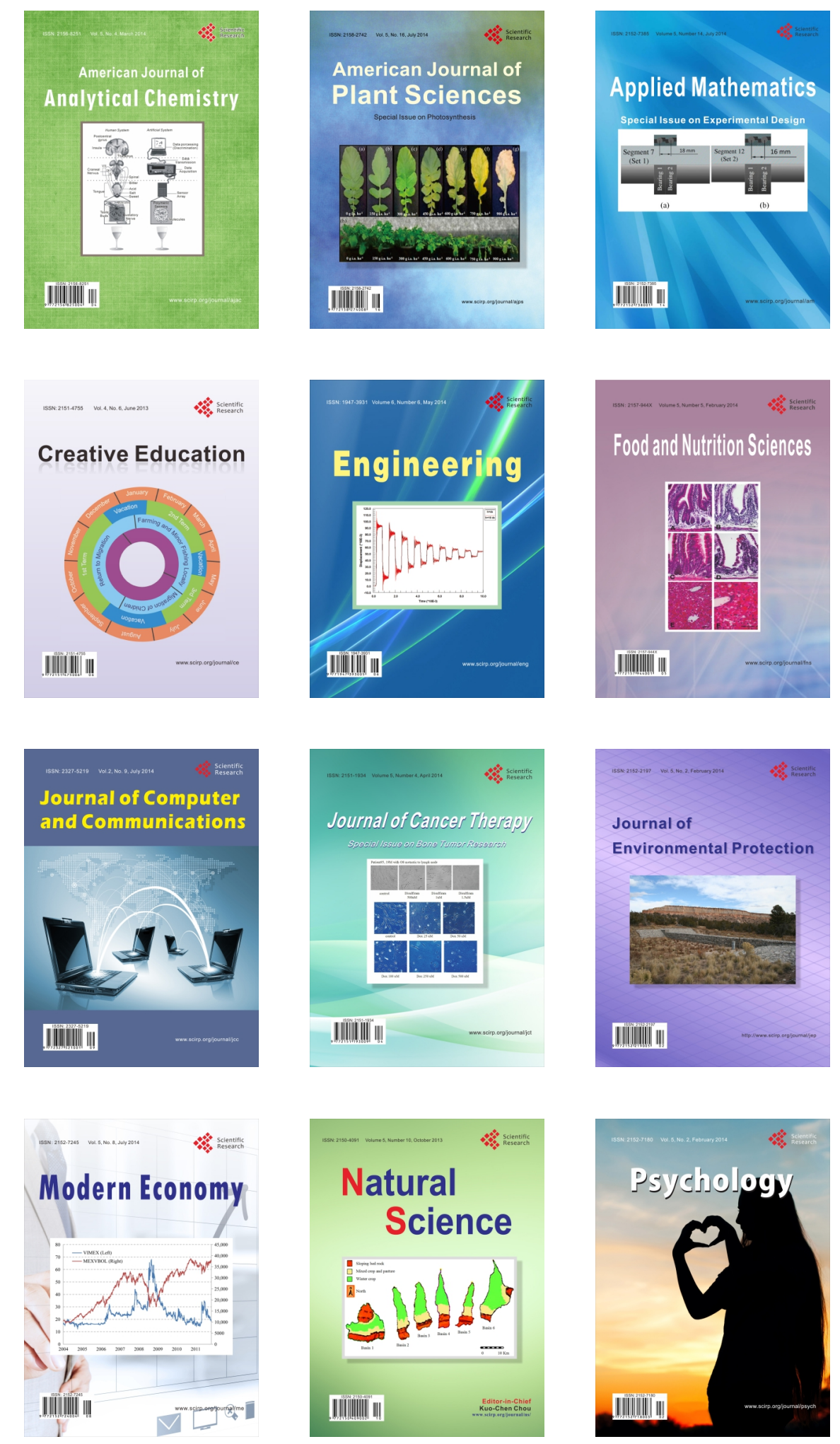